\title{
Exploring the Impact of VAK Learning Style on Teenager Level Language Learners in Indonesia
}

\author{
Rina Asrini Bakri \\ STKIP YPUP Makassar, Indonesia \\ M. Asfah Rahman \\ Universitas Negeri Makassar, Indonesia \\ Baso Jabu \\ Universitas Negeri Makassar, Indonesia \\ Jassruddin \\ Universitas Negeri Makassar, Indonesia
}

\begin{abstract}
This study aims at finding out whether Visual Auditory Kinesthetic (VAK) learning styles improve the It presents pre experimental design to see the impact of VAK learning style with one group pre-tested and post-tested, employing oral testing. The target group of this study was teenager level language learners at a school in Makassar Indonesia in the 2015/2016 academic year. Twenty nine students with average speaking ability participated in this study. A purposive sampling technique was used to recruit participants. The data was collected through an oral proficiency. The results of the data analysis indicated that there was a significant difference in the students' English speaking skills before and after being trained using the VAK learning style. Results indicated that post-test was greater than pre-test in accuracy, fluency, comprehensibility. Based on the result of analysis can be concluded that the adoption of the VAK learning style can improve the English speaking skills and the methodology can be used as a preliminary strategy to assess students' learning capability.
\end{abstract}

Index Terms - visual auditory kinesthetic learning style, English, speaking, teenager level

\section{INTRODUCTION}

Teaching English in the area of EFL has already conducted to the all scale of school in Indonesia. English has taught in the scale of elementary school, junior high, and senior high. As we know that, since English as the foreign language for the students there will be many gap that the learners got when studying English because it is only studied in an environment where it is not the primary vehicle for daily interaction. As the common problem faced that the learners are unmotivated. It might be caused by learners interpretation to English refer to the original of English has no similarities to Indonesian. Most of the learners are also not interested in learning because quite complicated subject to be learnt. Furthermore insufficient time becomes a matter in teaching English. The teaching time is often very short, so the teacher has no enough time to create an innovative lesson plan, the teacher also found difficulties in review the last meeting or material. This case also stated by (Syatriana, 2013) argues that English is taught as a foreign language in Indonesia with a very limited time and it is not used in everyday communication so makes the students are difficult to master the language. (Kartiah 2013) stated that the teachers of secondary school still face many problems in teaching English as a foreign language in the area of helping students understand the material which are being taught, the students feel bored and tired when learning English. It is probably caused by teachers who have not accommodated the difference of students' intelligence and learning style yet.

Learning style is one of the factors which affect students' achievements in learning. Learning style is a cognitive composite, affective, and psychological factor which acts as an indicator of how individuals interact and respond to the learning environment (Duff 2000). Students have different type of learning style based on their personality (Duff 2000). Teaching the students based on their learning style preference will help them to be more easily understand what they learn. It is therefore important for a teacher to know a students' preferred learning style, particularly in English teaching.

The teacher as facilitator plays a vital role in the teaching and learning process. A good teacher is always able to determine the most effective teaching method and media for their students. Besides, teacher should know or recognize more their students, because they come from very different backgrounds which have various learning needs and preferred learning styles. (Jalal, 2007) stated "as the educator input will affect the learners output, so the less of the students result or score can influence the quality of the educators". Therefore, teachers must be competent and professional, because they have good effect on the quality of teaching and the learning process.

As explained earlier, individual students use different learning styles due to their personal differences. Applying 
VAK (Visual Auditory and Kinesthetic) learning styles in a class to accommodate the students' learning style preference will likely bring good achievement in English speaking classes. An assessment of the appropriateness of the VAK leaning style is of potential value in helping decide on the appropriate learning style for improving students' speaking ability. Learning style is defined as a person's learning preferences to apprehend, organize, and process information and experiences in learning (Smith, 2010; Buali, 2013). There are three condition that influence the differences which already proven to the result of teaching and learning process; (1) the learners differences in learning styles, some methods to learning styles, (specific ways in capturing the useful attention); (2) the learning approach (superficial, depth, strategic.) and; (3) the development of inelegancy levels or affective to the real cognitive or thinking and the way of getting and testing). Felder \& Brent, (1996). Additionally, Felder (2005) stated that students' learning progress depends on the learning style, the fact that students focus on different types of information, and perceive information differently, and achieve an understanding at different rates.

In this study, the three learning styles with related activities in learning to speak English, have been evaluated. The first method is the visual learning style, the activities related to which involve watching videos or DVDs, describing photographs, and imagining something. The second method is the auditory learning style which includes activities like memorizing games, storytelling, and reading aloud. The third method is the kinesthetic learning style which includes activities like role playing, socio drama, and gesturing. These learning styles were selected based on Fleming (2001), according to this model he assumed that "each person has a dominant or preferred learning style" (Sashank Kodesia, 2013).

One of the important issues is that teachers or lecturers still face many problems in teaching English as a foreign language in the area of helping students understand the material which is being taught, and finding ways to prevent the students feeling bored and tired when learning English. This case is also described by (Ahmed, 2016) that the students have very limited time in learning English curriculum and lacking encouragement to practice English outside the classroom to get accustomed with English. Sometimes the student ability to speak English reflects whether the teachers have accommodated the differences in students' intelligence and learning style (Kartiah, 2013). Reflecting on the important role of learning styles in learning and academic achievements, the present study explored the impact of VAK learning style on adult beginner level language learners in speaking class at a secondary school in Makassar Indonesia.

\section{A. Background}

Understanding learning styles can be considered as one of the key components of managing classroom teaching strategies (Jaeger et al., 2007). The VAK learning style enables teachers to expand their repertoire, and strategies in teaching and learning processes. Most English teachers in secondary schools focus on linguistics and logistics when teaching in the classroom (Kartiah, 2014), and the authors have observed the similar in Makassar in general.. Also important is determining whether the teaching technique and subjects material are based on the learning styles identifications of the learners is one of the best way in the use of conventional way in teaching strategy. Those who have been taught based on their learning style preferences have been reported to have better performance in terms of speaking ability than those who were taught using traditional teaching methods which is more teacher centered and high reliance on written materials (Tulli et al., 2006).

The best definition of learning styles according to him is the truly way where learners learn the latest issue. Not many learners use dominant style, however most teachers have only one exclusive style in teaching. Only few people use one dominant style. Learners can study and learn more productively when the role is suitable to their learning style (Davidoff \& Berg, 1990). Furthermore, (Carson, 2010) after conducting research about the cultural values and factors that affect the learning of Latin American and Asian students suggested for teaching to preferred learning styles. In this case, teachers need to find in what ways the students learn best by knowing or indentifying the students' learning style preference first. By knowing it, a teacher can effectively design lessons to promote optimal learning for all students in the classroom.

Besides the students assert that self-esteem blossoms through successful learning, reinforcing a positive attitude toward future learning. Education researchers Dunn and Dunn reported that the educators be able to adopt every activity that apply individual group activities in the learning styles theory elaboration in a theme, group activities can be effective learning based on specific learning styles (Dunn and Dunn, 1990).

Real effect can appear and make the students become slow in improving their education (Higerson - Volk, 1987). It is also explained by Dunn and Sanders (1981) why the educators should have learning style awareness. Further, (Winetrenner, 1996) stated that the best strategy for students in fight by creating attention through teaching the learning styles they acquire. It is also assumes that there are the relations between the teacher teaching strategies and the students prior knowledge in learning.

In this case Teacher plays vital role in the classroom. De porter, (2001) states that learning style is a teacher plays a role to create a conducive condition so the students can be active in the teaching \& learning process. Furthermore (Jaeger et al, 2007) stated that learning style was assumed as a main teaching tool in managing classroom. Learning style activity as one of the possible answers that demand to accommodate differences of students' learning style in learning process. (Winebrenne, 1996) stated that students must be taught the learning styles in order to strengthening their knowledge when find the difficulties in learning. 


\section{B. Teaching Visual, Auditory, and Kinesthetic Learners}

Based on the theory of VAK learning style (LdPride, 2009) described VAK learning style as follows:

Visual learners learn best through viewing concepts or picture. They learn from reading, seeing, writing, and like written instructions, so they favor sitting in front of the class to take descriptive notes over the material being delivered. They learn best when they can observe, pictures, diagrams, films and displays. This type of learners depends on the instructor's nonverbal cues e.g. gesture or body language can help them to understand. Instructor must give kinds of media such as flashcards, webpage, and map as the students reference. They also will pay attention to the subject material by using checklist.

Auditory students master new material best through listening and interpreting information by the means of pitch, emphasis and speed. They gain knowledge from speaking information aloud or reading aloud in the class and repeating key concepts. Writing activity is a kind of learning which get the students to communicate and discuss by giving a loud information will show the core concepts. For the visual learners, they regard that auditory students prefer more about activity in terms of lecturing, debating, or even small group discussion. Teacher can be the best master of learning for learners by applying the repetition of main concepts in media such as music, and videos or film through oral presentation in the curriculum implementation.

Kinesthetic learners learn best when permitted to move, touch and get active in some ways; they favor interaction with the physical world, the teachers will do well to encourage and allow physical movement. Students who master kinesthetic can be fun by using tools that activate the body organs like hand. In the application of teaching study tour or direct observation in the lab is the best way for students in this style. This kind of learning style make the students become active in move about. Teaching the students who prefer kinesthetic in the classroom will useless because they tend to practice and touch or even perform what they learn about. Therefore teachers should accommodate the students need.

\section{METHOD}

\section{A. Participants}

The population for this research was the fourth semester students of secondary school Class XIII.3 of SMPN 1 Makassar, in the 2016 academic year. There were 29 students in the class. For student sampling for the research 2016, the researcher applied a purposive sampling technique and took class XIII.3, because based on evaluation of the previous semester's mark most of the students had the same level of speaking English ability.

This research was conducted to evaluate the students' improvement in terms of speaking based on the VAK learning style. The method and design applied a pre-experimental design with one group pre-test $\left(\mathrm{O}_{1}\right)$ and $\mathrm{E}$ post-test $\left(\mathrm{O}_{2}\right)$ design. There was treatment $(\mathrm{X})$ between pre-test and pos-test. The treatments involved four meetings of 120 minutes in each meeting. During the treatment, the students were taught through VAK learning style activities.

\section{B. Data Collection}

The researcher administered a pre-test to evaluate the students' prior speaking skills. Before giving the treatment, the researcher gave reading texts to the students'. The topics of the texts were: "National Examinations", "General Election", and "Negative Effects of Smoking". After giving the texts, the researcher asked the students to retell what they had read. Then, the students were given training about learning speaking through VAK learning style activities for six weeks (six meetings). In the treatment, the researcher provided some materials which covered the three types of learning style activity in each meeting. For visual learning style, the activities were: watching videos or DVDs, describing photographs, and imagining something. For Auditory style learning, the activities included memorizing games, learning from videos, storytelling, and reading aloud. The activities for the kinesthetic learning style were role playing, socio drama, and gesturing. After giving the treatments in terms of the VAK learning style activity, the researcher undertook a post-test of the class (an oral test).

Result

The measurement of the students' result in the speaking test and the raw score of the students obtained through the pre-test and post-test was tabulated and then analyzed in terms of percentage and mean score analysis. In determining the quality of students' score in the speaking test, their scores were classified into six levels as summarized in the following table: 
TABLE I

PERCENTAGE AND FREQUENCY OF THE STUDENTS' SCORE IN ENGLISH SPEAKING ACCURACY, FLUENCY, AND COMPREHENSIBILITY

\begin{tabular}{|c|c|c|c|c|c|c|c|c|c|c|c|c|c|c|}
\hline \multirow{3}{*}{ No } & \multirow{3}{*}{ Score } & \multirow{3}{*}{ Classification } & \multicolumn{4}{|c|}{ Accuracy } & \multicolumn{4}{|c|}{ Fluency } & \multicolumn{4}{|c|}{ Comprehensibility } \\
\hline & & & \multicolumn{2}{|c|}{ Pre-Test } & \multicolumn{2}{|c|}{ Post-Test } & \multicolumn{2}{|c|}{ Pre-Test } & \multicolumn{2}{|c|}{ Post-Test } & \multicolumn{2}{|c|}{ Pre-Test } & \multicolumn{2}{|c|}{ Post-Test } \\
\hline & & & Ereq. & \begin{tabular}{|l} 
Perc. \\
$\%$
\end{tabular} & Freq. & $\begin{array}{l}\text { Perc. } \\
(\%)\end{array}$ & Freq. & $\begin{array}{l}\text { Perc. } \\
\%)\end{array}$ & Freq. & $\begin{array}{l}\text { Perc. } \\
(\%)\end{array}$ & Freq. & $\begin{array}{l}\text { Perc. } \\
\%)\end{array}$ & Freq. & $\begin{array}{l}\text { Perc. } \\
(\%)\end{array}$ \\
\hline 1 & 6 & Excellent & 0 & 0 & 0 & 0 & 0 & 0 & 0 & 0 & 0 & 0 & 0 & 0 \\
\hline 2 & 5 & Very Good & 0 & 0 & 2 & 6.9 & 0 & 0 & 3 & 10.3 & 0 & 0 & 4 & 13.8 \\
\hline 3 & 4 & Good & 1 & 3.4 & 6 & 20.7 & 2 & 6.9 & 7 & 24.1 & 3 & 10.3 & 12 & 41.4 \\
\hline 4 & 3 & Average & 3 & 10.3 & 10 & 34.5 & 4 & 10.3 & 18 & 62.1 & 10 & 34.5 & 12 & 41.4 \\
\hline 5 & 2 & Poor & 14 & 48.3 & 10 & 34.5 & 22 & 44.8 & 0 & 0 & 15 & 37.9 & 0 & 0 \\
\hline 6 & 1 & Very Poor & 11 & 37.9 & 1 & 3.4 & 1 & 37.9 & 1 & 3.4 & 1 & 3.4 & 1 & 3.4 \\
\hline \multicolumn{3}{|c|}{ Total } & 29 & 100 & 29 & 100 & 29 & 100 & 29 & 100 & 29 & 100 & 29 & 100 \\
\hline
\end{tabular}

The data of students' accuracy in speaking shows the rate percentage and the frequency of the students' pre-test and post-test that there were variant scores on the table of the students' pre-test. It could be seen that from 29 students, there was one student $(3.4 \%)$ obtained "good", there were 3 students $(10.3 \%)$ out of 29 students obtained "Average" score, 14 $(48.3 \%)$ students obtained "Poor", and 11 (37.9\%) students obtained "Very Poor". While the rate percentage of the sudents' post-test can be seen that there was no students obtained "Excellent", 2 (6.9\%) students obtained "Very Good", $6(20.7 \%)$ students obtained "Good", 10 (34.5\%) students obtained "Average", there were $10(34.5 \%)$ students obtained "poor" and 1(3.4\%) student obtained "Very poor".

The data of speaking fluency shows the rate percentage and the frequency of students' pre-test and post-test that, there were $2(6.9 \%)$ students obtained "good", 4 (13.8\%) students obtained "average", 22 (75.9\%) students obtained "poor", and $1(37.4 \%)$ student obtained "very poor" score. While the frequency and rate percentage of the sudents' posttest can be seen that there was no student obtained "excellent" score, $3(10.3 \%)$ students obtained "very good", 7 $(24.1 \%)$ students obtained "good", 18 (62.1\%) students obtained "average",there was no student obtained "poor", and 1 $(3.4 \%)$ student obtained "very poor" score. Based on the result, it could be concluded that the rate percentage in the post-test were higher that the rate percentage in pre-test.

The data of speaking comprehensibility shows the rate percentage and the frequency of the students' pre-test and post-test that, there were $3(10.3 \%)$ students obtained "good", there were $10(34.5 \%)$ students obtained "average", 15 $(51.7 \%)$ students obtained "poor", and $1(13.4 \%)$ students obtained "very poor" score. While the frequency and rate percentage of the sudents' post-test could be seen that there was no student obtained "excellent" score, 4 (13.8\%) students obtained "very good", 12 (41.4\%) students obtained "good", there were 12 (41.4\%) students obtained "average", there was no student obtained "poor", and 1 (3.4\%) student obtained "very poor" score. Based on the result, it could be concluded that the rate percentage in the post-test were higher that the rate percentage in pre-test.

Based on the data got, it can be concluded that the rates in the post-test were higher than the rates in the pre-test.= VAK learning styles had improved the speaking English ability of the students, indicated by the three components of speaking, i.e. accuracy, fluency and comprehensibility (Table 1).

The Improvement of Students' Speaking Skill Through VAK Learning Style activities.

The material used in VAK learning style was interesting for the students, so that the students did not feel bored during the research applied. The material and the strategy delivered based on (LdPride, 2009) theory about learning style. Teaching speaking using the VAK learning style activity, the accuracy, fluency, and comprehensibility were improved which was applied at the fourth semester at one of the the secondary school in Makassar Indonesia.

\section{Accuracy}

The researcher compared t-test values and t-table values to know whether the use of the VAK learning style activity in teaching speaking accuracy was significant and improved learning efficiency. The degrees of freedom (df) the researcher used formula $\mathrm{N}-1=29-1=28$, for the level significant (p): 0.05 and $\mathrm{df}=28$ and the t-table achieved a score of 2.048 after calculating the t-test value, t-test obtained score 13.892 then comparing with t-table and t-test (13.892 2.048). This result meant that there was a different result for the value of the t-test and t-table. This means that, the use of the VAK learning style activity was effective for improving the students' speaking skills in term of accuracy.

The data indicates that the score in the post-test was greater than the pre-test (Graph 1). The percentage also indicated that the students' accuracy was high. The students' pre-test score was 1.79, whereas their post-test score is 2.93 . There was improvement of the students' achievement in speaking accuracy in response to VAK learning style, the improvement being $63.69 \%$.

\section{Fluency}

The researcher compared the t-test value and t-table value to establish whether the use of VAK learning style activity in teaching speaking fluency was significant and effective, and to find out the degree of freedom (df) the researcher used the formula $\mathrm{N}-1=29-1=28$, for the level significant $(\mathrm{p})$ : 0.05 and $\mathrm{df}=28$ and t-table achieved a score 2.048 after calculating the t-test value. The t-test achieved a score of 13.892 . 
The result of the research found that the students'fluence score in the pre-test was 2.24 while the students' score post-test was 3.38. This was considered as good result in response to the use of the "VAK learning style activity" to improve the level of students' fluency in speaking. The students'fluence score in the pre-test was 2.24 whereas the students' score post-test was3.38. This was considered as good result in response to the use of the "VAK learning style activity" to improve the level of students' fluency in speaking.

\section{Comprehensibility}

The result of research indicates that the score of the post-test was greater than the pre-test. This meant that the teaching in speaking comprehensibility by using VAK learning style activity was effective for the students. There was a $43.65 \%$ improvement in speaking comprehensibility of the students from the use of the use of the "VAK learning style activity".

Based on the pre-test and post-test scores for accuracy, fluency, and comprehensibility, there were significant improvements in the students' speaking skills. It is concluded that the students' improvement in speaking accuracy was greater than the improvement of the students' speaking fluency and comprehensibility, (Graph 1).

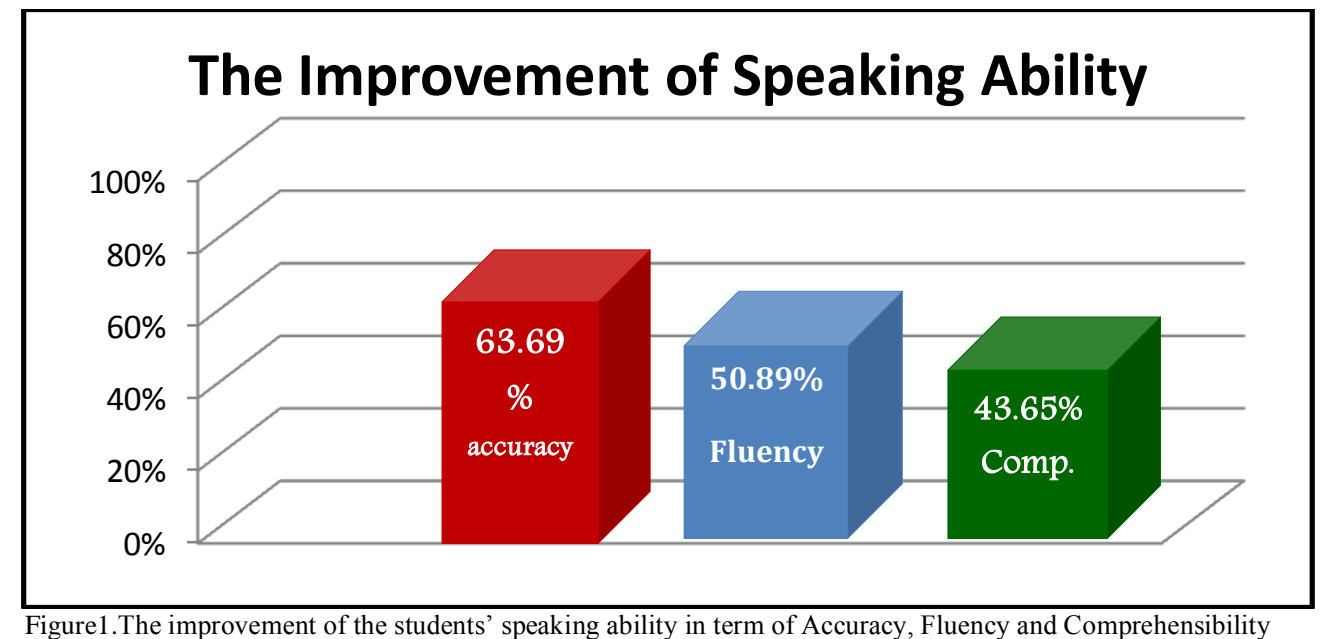

\section{DISCUSSION}

Discussion dealt with the interpretation of the students' activities and the findings derived from the result of statistical analysis during the classroom interaction.

The study results showed that the students' English speaking ability improved significantly by using VAK learning style activity. It is one way to accommodate the students' learning preference in speaking by offering them various materials which cover the three types of learning style activities.

Based on the findings of this study, an improvement was shown in the results for the pre-test to post-test. In the pretest, the researcher found that some of the students' speaking skills (accuracy, fluency, and comprehensibility) were still low. The researcher therefore decided to use VAK learning style activity and accommodate the students' learning style preference in learning speaking. In the first treatment students did not appear to be enthusiastic indicated by some of the students who did not paying attention or not participating) in following the material. Only a small number of students were active in the speaking class based on the use of the VAK learning style activity. Therefore, in the second treatment, the researcher tried to give more interesting materials to make the students more active in the classroom interaction. The result was the students showed an improvement in the class, they were actively participating in the class with the material given. In the third treatment the students really enjoyed the activity, it can be seen from their higher participation level during the class, because the researcher gave comprehensive explanations and motivated the students during the classroom interactions. The researcher also provided some uncommon vocabularies with their translation during treatment, so that the students found the English terms easy to understand. Finally, in the post-test after VAK learning style activity, the researcher found that there was significant improvement in the students' speaking skills.

There are some limitations identified relating to the students' speaking skills when using the VAK learning style activity. It was still difficult to create an enjoyable environment and make students active in the class. A more pleasant environment by giving interesting materials and clear explanation and being is needed in the future study. Providing some uncommon vocabularies with the translation to assist the students in understanding the materials can also be an alternative strategy to motivate participants.

The researcher presented the discussion about the data analysis on the research that has been presented in the previous part. In this case the researcher divided discussion into three parts: part (1) discussion about data analysis, which is intended to find out the improvement of students' speaking accuracy through VAK learning style activities , it can be identified through the result of pre-test and post- test, (2) the discussion about the improvement of students' 
fluency in learning English speaking through VAK learning style activities that can be analyzed from the result of pretest, and post-test, and (3) discussion about data analysis, which is intended to find out the improvement of students' comprehensibility through VAK learning style activities, it can be identified through the result of pre-test and post- test.

\section{A. The Students' Achievement in Speaking Accuracy}

The description of data collected through the test as explained previously that the students' knowledge about the improvement in speaking accuracy through VAK learning style activity was significant. It was supported by t-test value of the students was greater than t-table.

By applying VAK learning style activities in the class, the researcher found that the mean score of post-test of students' achievement in speaking accuracy was greater than pre-test, that in pre-test obtained 1.79 and after treatment obtained 2.93. So, it can be indicated that there was significant improvement of the students' speaking accuracy by VAK learning style activity as one way in teaching speaking.

The improvement of the students' speaking accuracy was $63.69 \%$. It meant that there was significant of speaking accuracy after teaching by VAK learning style activity. Therefore the result of data analysis from the students' improvement in speaking accuracy toward post test indicated that value of t-test (13.892) greater than t-table (2.048).

\section{B. The Students' Achievement in Speaking Fluency}

By applying VAK learning style activity, it was found that the mean score of post-test of students' achievement of speaking fluency was greater than pre-test, it is shown that in pre-test obtained 2.24 and after treatment obtained 3.38, therefore the researcher indicated that there was significant improvement of the students' speaking fluency by using VAK learning style activity.

The improvement of the students' speaking fluency was 50.89\%. It meant that there was significant improvement of speaking fluency. Therefore the result of data analysis from the students' achievement in speaking fluency toward post test indicated that value of t-test (13.892) was greater that t-table (2.048).

\section{The Students' Comprehensibility Achievement}

The researcher found that the mean score of post-test of students' achievement of speaking comprehensibility was greater than pre-test, it is shown that in pre-test obtained 2.52 and after treatment obtained 3.62, therefore the researcher indicated that there was significant improvement of the students speaking fluency by using Socratic Seminar method.

The improvement of the students' comprehensibility was $43.65 \%$. It meant that there was significant improvement of students' comprehensibility. Therefore the result of data analysis from the students' achievement in students' comprehensibility toward post test indicated that value of t-test (14.520) was greater that t-table (2.048).

The final result to this study highlight the importance learners learning style in helping them to achieve the best knowledge outcome. The researcher found the significance difference between the result of learning style and academic result. There was a significant improvement in students speaking skills in response to the VAK learning style activity of teenager level at one of secondary school in Makassar Indonesia. A research by (Koch et al., 2011) the research sample was nursing students in Australia, students are given the questionnaire of VAK, and the result reported that learning styles as the strategy in empowering the academic result. A research by (Fleming et al., 2011) in addition (Vizeshfar, \& Torabizadeh, 2018) stated that it is crucial to give extra attention of the learners learning preferences than to teach them conventional way. Therefore, considering students' learning style when delivering the learning materials will affect students' learning outcomes.

\section{Conclusion}

Both teachers and students are sometimes not satisfied with teaching materials provided and teaching strategies. It is therefore important for both teachers and students, to provide the appropriate learning materials and adopt the appropriate teaching strategy. The learning activity should reflect the students' learning style preference. The result of the study indicates that the adoption of the VAK learning style activity affects the students' learning achievements, and it can build up their confidence in learning a language, especially speaking skills.

This study concluded that there was a significant improvement in the students' speaking skills in response to using the VAK learning style activity in the class. This was clearly reflected in the improvement in the students' speaking skills. The results of this study and other similar studies clearly indicate that different teaching methods and strategies can potentially impact on student response, and that it is important to take into account the students' learning preference to achieve the best outcome in language learning. English teacher should use various methods, strategy, or techniques, in teaching and learning process to avoid the monotonous classroom activities. VAK learning style can be considered as the preliminary strategy to asses student's learning capability. For further research, it is important to design material which can accommodate the students' learning style, to motivate, and attract students' interest which will give good effect on their learning outcomes. Also, there are still many things to be observed by further researcher related to the English speaking skill because this study just focused speaking skill towards the use of VAK learning style activities.

\section{ACKNOWLEDGEMENTS}

The researcher addresses thank to Direktorat Kualifikasi Sumber Daya Manusia, KEMRISTEK DIKTI (Ministry of 
Research, Technology and Higher Education of Indonesia for the financial support (PKPI Program 2017), State University of Makassar, The University of Queensland and STKIP YPUP Makassar. Big thank also goes to Dr. Shirin m. Hassan Jamarani dan Dr. Yulina Eva Riani for guiding and mentoring the researcher during writing this article at University of Queensland.

\section{REFERENCES}

[1] Alberta L. (2002). Instructional Strategies; Health and Life Skills Guide to Implementation (K-9) @Alberta Learning, Alberta, Canada. Retrieved from: https://education.alberta.ca/media/352984/is.pdf (accessed 11/3/2018).

[2] Byrnes, S. (2010). Assimilative domain proficiency and performance in chemistry coursework (Doctoral dissertation). Available from ProQuest Dissertation and. Theses databases. (UMI No.3397866).

[3] Becker, K., Kehoe, J., \& Tennent, B. (2007). Impact of personalised learning styles on online delivery and assessment. Campus Wide Information Systems, 24(2), 105-119. (accessed 11/3/2018).

[4] Brown, H. Douglas. (1994). Teaching by Principle: an Interactive Approach to Language Pedagogy. New Jersey: Prentice-Hall. Lnc.

[5] Buali, W.H., Balaha, M.H., Al Muhaidab, N.S. (2013). Assessment of learning style in a sample of Saudi medical students. Acta Inf. Med. 21 (2), 83-88.http://dx.doi.org/10. 5455/aim.2013.21.83-88. (accessed 1/2/2017).

[6] Duff, A. (2000). Learning style of UK higher education students: Four studies of the reliability and replicability of the learning style questionnaire (LSQ). Bristol Business School Teaching and Research Review, 14 (3), 131-177.

[7] Dunn, R. S., \& Griggs, S. A. (2000). Practical approaches to using learning styles in higher education. Westport, CT: Greenwood publishing group.

[8] Dunn, R. (1990). Understanding the Dunn and Dunn learning styles model and the need for individual. Journal of Reading, Writing, and Learning Disabilities International. (accessed 7/11/2017).

[9] Fleming, S., Mckee, G., Huntley-Moore, S. (2011). Undergraduate nursing students learning style: a longitudinal study. Nurse Educ. Today 31 (5), 444 -449. http://dx.doi.org/10.1016/j.nedt.2010.08.005.

[10] Fleming, S., Mckee, G., Huntley-Moore, S. (2011). Undergraduate nursing students learning style: a longitudinal study. Nurse Educ. Today 31 (5), 444-449. http://dx.doi.org/10.1016/j.nedt.2010.08.005.

[11] Fleming, N. (2001-2011). VARK A guide to learning styles. Retrieved 24/08/2014 from: http://www.varklearn.com/english/page.asp?p=aural.

[12] Gay, L.R. (1981). Education Research Competencies for Analysis and Application. Colubus: Bell and Howell Company.

[13] Heaton, J.B. (1991). Writing English Language Test. New York: Longman Inc.

[14] Jalal, Fasli. (2007). Sertifikasi Guru Untuk Mewujudkan Pendidikan yang Bermutu. http://www.sertifikasiguru.org/. (accessed 30/6/2018).

[15] Jaeger, B., Freeman, S., \& Whalen, R. (2007). AC 2007-1236 do the like what they learn, do they learn what they like and what do we about it. Washington, DC: American Society for Education Engineering.

[16] Kavi. Havriye. (2003). Teaching Speaking: Activities to Promote Speaking in a Second Language. [Online]. Hhtp://unr.edu/homepage. Diakses Tnggal 29 Maret 2013.

[17] Kartiah, Raden. (2014). Designing English Teaching Learning Program for Junior Secondary School Students Based on Multiple Intelligence Theory. Dissertation. Unpublished. State University of Makassar.

[18] Koch, J., Salamonson, Y., Rolley, J.X., Davidson, P.M. (2011). Learning preference as a predictor of academic performance in first year accelerated graduate entry nursing students: a prospective follow up study. Nurs. Educ. Today 31 (6), $611-616$. http://dx.doi.org/10.1016/j.nedt.2010.10.019.

[19] LdPride,n.d. (2009). What are learning styles? Retrieved from http://www.ldpride.net/learning styles .MI.htm. (accessed 16/9/2017).

[20] MacKeracher, D. (2004). Making sense of adult learning, (2nd ed.). Canada: University of Toronto Press Incorporated.

[21] Magri, Al. (2013). Ciri Gaya Belajar Anak Visual Auditori Kinestetik. [Online]. http://www.almaghribicendekia.com/2013/04/ciri-gaya-belajar-anak-visual.html. Diakses Tanggal 29 Maret 2013.

[22] Mastura. (2002). Teaching Reading Comprehension by Using Sequence Pictures of the Third Year Student in SMPN 1 Maiwa. Enrekang. A Thesis. Makassar: The State University of Makassar.

[23] Nurlaila, St. (2005). The Interest of the Second Year Students of SMAN 2 Mamuju to Speak English Through Group Discussion. A Thesis. Makassar: The State University of Makassar.

[24] R.M. Felder and R. Brent, (2005). Understanding Student Differences. J. Eng. Education, 94 (1), 57-72 (2005)

[25] Smith, M.K., (2010). 'David A. Kolb on experiential learning', the encyclopedia of informal education. Avilable. http://www.infed.org/biblio/b-explrn.html Accessed may 2015.

[26] Syatriana, Eny. (2013). Designing English Instructional Materials for EFL Senior High School Students Based on School Curriculum. Dissertation. Unpublished. State University of Makassar.

[27] Tuli, S.Y., Thompson, L.A., Saliba, H., Black, E.W., Ryan, K.A., Kelly, M.N., Novak, M., Mellott, J., Tuli, S.S., (2011). Pediatric residents learning style and temperaments and their relationships to standardized test scores. J. Grad. Med. Educ. 3 (4), 566-570. http://dx.doi.org/10.4300/JGME-D-10-00147.1.

[28] The Asian Conference on Education. (2013). Official Conference Proceedings The Relationship between Students' Learning Style and Academic Performance in Mara Professional College, Malaysia Mumtaz Begam Binti Abdul Kadir MARA Professional Colleges, Malaysia The Asian Conference on Education 2013 Official Conference Proceedings.

[29] Vizeshfar, \& Torabizadeh. (2018). The effect of teaching based on dominant learning style on nursing students' academic achievement. Nurse Education in Practice, 28, 103-108. 


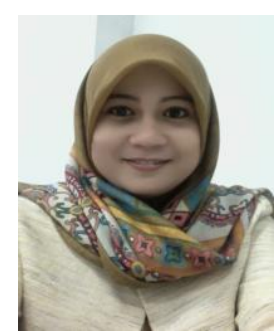

Rina Asrini Bakri was born in Watampone, on January $22^{\text {th }} 1985$, in South Sulawesi, Indonesia. She is the second child of Muh. Bakri dan Nursiah. She completed her undergraduate study in 2007 in English Education at Universitas Negeri Makassar. She earned her Master degree from State university of Makassar in Indonesia. Her research interest is in Teaching English as Foreign language. She is a lecturer at STKIP YPUP Makassar. She is currently a Doctorate student at Universitas Negeri Makassar. She attended some International Conference as the Presenter. Namely: The Presenter in International Conference of Language Education (ICOLE). The Presenter in Seminar Presentation of PKPI Program Queensland University, Australia (2017). Memorabilia Portfolio for Better Writing Quality, published in Proceeding International Conference on Language Education in 2013. Teaching speaking through interpersonal interaction. Published in RENAISSANCE JOURNAL 2014. The Effect of Inductive Approach in Teaching Grammar at English Department Students of STKIP YPUP Makassar. Published at Al-ADABI JOURNAL 2016. Empowering Speaking Ability for Students using Psychology Game Technique to the second Grade Students at SMA Bulukumba at Journal of Advanced English Studies 2018

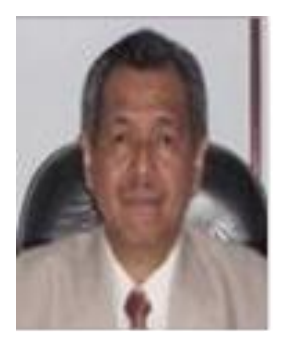

Muhammad Asfah Rahman was born in Selayar, South Sulawesi, Indonesia on May 21, 1952. He completed his undergraduate study in 1979 in Teaching English as a Foreign Language (TEFL) at Ujung Pandang Institute of Teacher Training and Education) in Makassar, Indonesia and master and doctorate degrees in the field of Instructional Design and Technology at the University of Pittsburgh, PA, USA in 1986 and 1990 respectively. He is currently a professor in the Faculty of Literature and Language, State University of Makassar, in Makassar, Indonesia. He has a lot of experience in elementary and secondary school teacher training, teacher professional development, and teaching English to young learners. He was employed for five years as ACADEMIC ADVISOR for USAID Decentralized-Basic Education leading university faculty members to develop active learning training packages for elementary school teachers. In the last couple of years, he did a research and a development study whose product is a training package for elementary school teachers of English. At present, his research focuses on module development for improving EFL college writing. He has got the Best Paper Awards on his article entitled "Reading in English as a Foreign Language: A Case of First Year Students of Junior Secondary Schools in South Sulawesi Indonesia" from the 2nd International Conference on Theory \& Practice (ICTP-2016) of Asia Pacific Institute Advanced Research. His research interests include early reading program for learners of English as a foreign language. Prof. Rahman is a member of Indonesian Linguistics Society (MLI), Indonesian Education Scholars Association (ISPI), and TEFLIN (Teaching English as a Foreign Language in Indonesia).

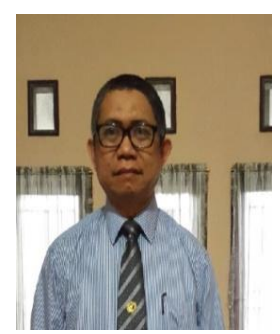

Baso Jabu completed his undergraduate studies in 1987, majoring in Teaching English as a Foreign Language (TEFL) at Ujung Pandang Institute of Teacher Training and Education (currently Universitas Negeri Makassar), Indonesia. He completed his Master's and doctoral degrees in the field of applied linguistics at Hasanuddin University in Makassar, Indonesia, in 1995 and 2007, respectively. He was awarded a Specialist Certificate in Language Testing at the Regional Language Centre Singapore in 1996. Professor Jabu is former Director of the Language Centre at Universitas Negeri Makassar, where he manages training in some foreign languages, as well as the Indonesian language for non-native speakers. He is currently as the Second Assistant Director of Postgraduate Program of Universitas Negeri Makassar. He is a lecturer, and has been teaching English as a foreign language at Universitas Negeri Makassar for more than 20 years. Prof. Jabu is a member of TEFLIN (Teaching English as a Foreign Language in Indonesia) and MLI (Indonesia Linguistic Society). His research interests are TEFL and language assessment.

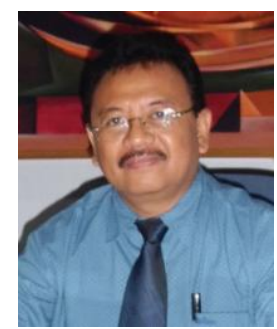

Jasruddin was born in Matano, South Sulawesi, Indonesia on Desember 22, 1964. He completed his undergraduate study in 1990 at Ujung Pandang Institute of Teacher Training and Education in Makassar, Indonesia. Then he continued his magister and doctorate degree in Bandung institute of Technology in 1996. $\mathrm{He}$ is a lecturer, and has been teaching Physics for more than 20 years at Universitas Negeri Makassar.His research interest is semiconductor physics material, especially silicon amorf (a-Si) in making Thin Film Transistor (TFT), Thin Film Light Emitting Diode (TFLED), and Solar Cell. He was also a director of Pasca Sarjana Universitas Negeri Makassar. He is currently as director of L2 DIKTI area IX Sulawesi. 